\title{
Prevalensi dan Derajat Infeksi Dactylogyrus sp. pada Insang Benih Bandeng (Chanos chanos) di Tambak Tradisional, Kecamatan Glagah, Kabupaten Lamongan \\ Prevalence and Infection Level of Dactylogyrus sp. on Gill of Milkfish Juvenile (Chanos chanos) in Traditional Pond, Glagah Subdistrict, Lamongan Residence
}

\author{
Faisol Mas'ud
}

Fakultas Perikanan Universitas Islam Lamongan

Jl. Veteran No. 53 A - Lamongan, Telp. 0322 - 324706

\begin{abstract}
The aim of research was to know prevalence and infection level of Dactylogyrus sp. on gill of milkfish juvenile (Chanos chanos) in traditional pond, Glagah Subdistrict, Lamongan Residence. It was using sample of 5 milkfish juvenile and for each treatment three replication. Researh design was Complete Random Design and continued by Analysis of Variance (ANOVA) and Least Significant Difference (LSD) 5\%.

The result showed that prevalence of Dactylogyrus sp. on gill of milkfish juvenile in Dalung village and Pedurungan village were significantly of $53.33 \%$ and $86.67 \%$, respectively. Furthermore, infection level of Dactylogyrus sp. on gill of milkfish juvenile were significantly on all of area.
\end{abstract}

Keywords : milkfish juvenile (Chanos chanos), Dactylogyrus sp., prevalence, infection level

\section{Pendahuluan}

Latar Belakang

Bandeng (Chanos chanos) merupakan ikan bernilai ekonomis penting yang banyak di pelihara di tambak-tambak air payau di Indonesia. Ikan ini merupakan konsumsi yang berperan penting dalam memenuhi kebutuhan protein masyarakat karena harganya relatif murah. Untuk memenuhi kebutuhan protein masyarakat budidaya bandeng telah berkembang dengan pesat.

Tambak bandeng (C.chanos) di Indonesia mencapai 184.000 Ha dengan produksi kurang lebih $360 \mathrm{~kg} / \mathrm{Ha} / \mathrm{Th}$. Sedangkan menurut Dirjen Perikanan (1981) produksi ikan bandeng (C.chanos) pada tahun 1979 rata - rata $515 \mathrm{Kg} / \mathrm{Ha} / \mathrm{Th}$. Hasil tersebut masih jauh di bawah negara-negara asia Tenggara lainnya seperti Filipina dan Taiwan. Di Taiwan luas tambak bandeng (C.chanos) hanya $15.000 \mathrm{Ha}$ namun dapat mencapai hasil $2.000 \mathrm{Kg} / \mathrm{Ha} / \mathrm{Th}$ (Anonim, 1990).1Dalam budidaya bandeng (C.chanos), salah satu masalah yang dihadapi adalah adanya ketersediaan benih bandeng (C.chanos) yang mencukupi. Kebutuhan akan benih bandeng (C.chanos) di Indonesia diperkirakan sekitar 1.209 juta ekor per tahun (Anonim, 1990). Kebutuhan akan benih bandeng baru terpenuhi sekitar $63 \%$. Diduga perkembangan industri penangkapan ikan tuna akhir - akhir ini yang menggunakan ikan benih bandeng (C.chanos) ukuran 200-300 gr sebagai umpan untuk meningkatkan kebutuhan akan benih bandeng (C.chanos). Disamping itu sejak tahun 1987 pemerintah membuka peluang ekspor benih bandeng (C.chanos) dengan kuota ekspor 600 juta ekor per tahun yang berarti kebutuhan benih akan meningkat dengan pesat (Anonim, 1988).

Faktor penting yang perlu diperhatikan dalam menunjang keberhasilan usaha pembenihan adalah penyediaan lingkungan yang sesuai atau dikehendaki benih bandeng (C.chanos) sehingga diperoleh kelangsungan hidup yang tinggi. Beberapa faktor yang perlu diperhatikan dalam budidaya bandeng (C.chanos) tradisional diantaranya adalah oksigen terlarut, salinitas, suhu, $\mathrm{pH}$, serta senyawa kimia seperti $\mathrm{NH}_{3}$. Perkembangan parasit dan penyakit di pacu seiring dengan memburuknya kualitas lingkungan perairan (Cameron, A. 2002). Perkembangan penyakit parasiter ini perlu di pantau setiap saat, sehingga wabah penyakit yang besar dapat dihindari.

Untuk memonitor populasi suatu parasit pada ikan dapat dilakukan dengan melakukan identifikasi parasit yaitu dengan cara menghitung Prevalensi dan Derajat infeksi. Prevalensi adalah presentasi ikan yang terserang parasit atau proporsi dari organisme-organisme dalam keseluruhan populasi yang ditemukan terjadi pada ikan pada waktu tertentu dengan mengabaikan kapan mereka terjangkit. Sedangkan Derajat infeksi adalah jumlah rata-rata parasit per ikan yang terinfeksi dinyatakan dalam parasit/ekor (Mulyana et al., 1990).2Jenisjenis parasit yang sering menyerang benih bandeng adalah Dactylogirus sp, Gyrodactylus $s p$, Ichtyopthirius sp, Lernaea sp, Myxobolus sp, dan Tricodina sp (Mulyana et al., 1990). Pada tahun 1990 serangan penyakit Dactylogirus sp dapat menyebabkan kematian sekitar $50 \%$ dari ikan yang 
terinfeksi. Hal tersebut menunjukkan bahwa Dactylogirus sp merugikan dan berbahaya bagi usaha budidaya bandeng, terutama ukuran benih (Kabata, 1985).

Dactylogirus $s p$ merupakan parasit yang sering menyerang pada insang terutama pada ikan bandeng. Parasit ini selama hidupnya berada pada tubuh ikan dan hanya akan meninggalkan inangnya apabila inangnya mati, kemudian ratusan larva Dactylogirus sp menetas dan mencari inang baru. Dampak infeksi Dactylogirus sp yang cukup berbahaya adalah menyerang pada insang dengan menggunakan kaitnya yang menyebabkan warna filamen insang sedikit pucat. Pendarahan terjadi seiring dengan terjadinya kerusakan dan kehancuran Lamella insang dan darah menggumpal sehingga proses respirasi terganggu (Scholz, 1999). Menurut Scolz (1999) benih bandeng (C.chanos) umumnya rentan terhadap parasit Dactylogirus sp yang biasanya menyerang pada insang. Sehingga pengamatan prevalensi dan derajat infeksi sangat penting dilakukan untuk mengetahui tingkat serangan dan penyebaran parasit pada suatu perairan yang selanjutnya dapat digunakan sebagai bahan pertimbangan dalam usaha penanggulangan dan pencegahan wabah parasit pada ikan khususnya bandeng (C.chanos) (Kabata, 1985).

Sampai saat ini penelitian mengenai infeksi ektoparasit Dactylogirus sp pada benih bandeng (C.chanos) di kecamatan Glagah kabupaten Lamongan belum dilakukan. Dari kejadian ini maka sangat penting dilakukan penelitian tentang infeksi ektoparasit Dactylogirus sp pada benih bandeng (C.chanos) di kabupaten tersebut, karena benih ikan umumnya rentan terhadap serangan parasit sehingga dapat menimbulkan kerugian cukup besar.

Identifikasi Masalah

Ikan benih bandeng (Chanos chanos) yang ada di desa Dalung, desa Pedurungan, dan desa Rayung kecamatan Glagah kabupaten Lamongan rentan terinfeksi parasit Dactyogyrus $s p$ dengan melihat penyediaan sistem lingkungan yang tidak sesuai atau dikehendaki pada ikan benih bandeng (Chanos chanos).

Batasan Masalah

Penulis membatasi pembahasan penelitian ini dengan mengidentifikasi penyakit parasit Dactylogyrus sp di desa Dalung, desa Pedurungan, dan desa Rayung kecamatan Glagah kabupaten Lamongan.
Perumusan Masalah

Dari latar belakang diatas didapat permasalahan bagaimana prevalensi dan derajat infeksi Dactylogyrus sp pada insang benih bandeng (Chanos chanos) di tambak tradisional kecamatan Glagah kabupaten Lamongan.

\section{Hipotesa Penelitian}

1. Diduga nilai tingkat prevalensi Dactylogyrus $s p$ pada insang benih bandeng (Chanos chanos) berturut turut.

2. Diduga derajat infeksi Dactylogyrus $s p$ pada insang benih bandeng (Chanos chanos) terdapat perbedaan.

\section{Tujuan Penelitian}

Tujuan dari penelitian ini adalah unutuk mengetahui prevalensi dan derajat infeksi Dactylogyrus sp pada insang benih bandeng (Chanos chanos) di kecamatan Glagah kabupaten Lamongan.

Kegunaan Penelitian

Hasil penelitian ini dapat digunakan sebagai data dasar untuk instansi terkait dalam usaha pengendalian penyakit ikan dan sebagai bahan pertimbangan dalam persiapan tambak bandeng (Chanos canos) untuk pencegahan terjadinya penyakit pada budidaya bandeng terutama di kecamatan Glagah kabupaten Lamongan sehingga dapat mengantisipasi dan mengurangi terjadinya penurunan produksi dan kualitas produksi.

\section{Tinjauan Pustaka}

Morfologi Ikan Bandeng (Chanos chanos)

Ikan bandeng bentuk tubuhnya ramping, mulut terminal, tipe sisik cycloid, Jari - jari semuanya lunak, jumlah sirip punggung antara 13 17 , sirip anal $9-11$, sirip perut $11-12$, sirip ekornya

panjang dan bercagak, jumlah sisik pada gurat sisi ada 75 - 80 keping, panjang maksimum 1,7 in biasanya 1,0 in (Moyle and Joseph, 2000).

Secara taksonomi sistematika bandeng menurut Nelsen 1984 adalah sebagai berikut :

$\begin{array}{ll}\text { Phylum } & \text { : Chordate } \\ \text { Subphylum } & : \text { Vertebrate } \\ \text { Superklas } & : \text { Gnathostomata } \\ \text { Klas } & : \text { Osteichthyes } \\ \text { Subklas } & : \text { Teleostei } \\ \text { Ordo } & : \text { Gonorynchiformies } \\ \text { Subordo } & : \text { Chanoidei } \\ \text { Famili } & : \text { Chanidae }\end{array}$




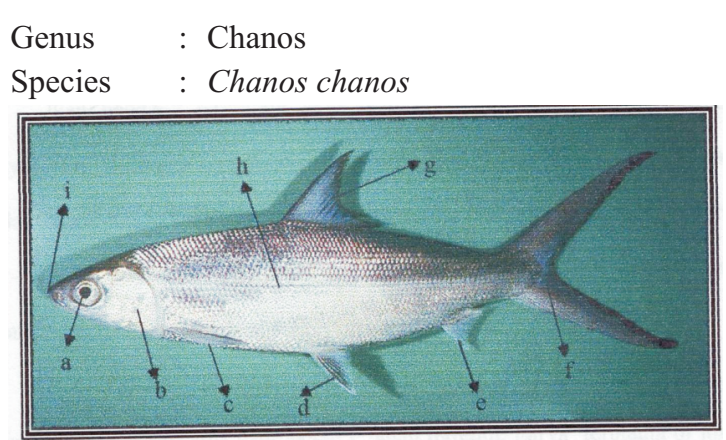

Gambar 1. Morfologi Bandeng (Chanos chanos), Keterangan : Mata (a), Tutup insang (b), Strip pectoralis (c), Strip abdominalls (d), Strip analis (e), Strip caudal (f), strip dorsalis (g), Linea lateralls (h), Mulut (1).

Sumber : Moller, 1986

\section{Habitat Ikan Bandeng (Chanos chanos)}

Ikan Bandeng di alam bebas hidup di laut, telurnya di temukan pada jarak 8 - 26 Ion dart pantai pada laut yang dalamnya lebib dari 40 in, telurnya terapung melayang dekat pennttkaan air. Memijah diwaktu malam sekitar 20.00 - 22.00 dan telurnya menetas sesudah 24 jam. Larva ikan bandeng dalam pertumbuhannya mendekati pantai dan diketemukan dua kali setahun di dekat pantai - pantai yang berpasir ditempat - tempat tertentu (http://www. Seafdec.com/milk fish.htm).

Ikan bandeng termasuk jenis ikan pelagis yang mencari makanan di daerah pennuk-aan dan sering di jumpai di perairan dekat pantai atau daerah litoral. Secara geografis ikan in] hidup di daerah tropis maupun sub tropis antara $30^{\circ}-40^{\circ}$ LS dan antara $40^{\circ} \mathrm{BT}-100^{\circ}$ BB. Ikan ini suka hidup bergerombol dalam kelompok kecil antara $10-20$ ekor. Berenang di perniukaan perairan pantai terutama pada saat air pasang (Ahmad dan Ratnawati, 2002).

Ikan bandeng tergolong jenis ikan euryhelline yaitu mempunyai daya penyesuaian (toleransi) yang tinggi terhadap perubahan kadar garam perairan mulai $0-60 \%$. Salinitas yang balk untuk perturnbuhan bandeng berkisar antara 2030 $\%$. Selain itu ikan bandeng juga memiliki ketahanan terhadap suhu perairan yang tinggi mencapai $40^{\circ} \mathrm{C}$ (Girl el al, 1986).

Secara alami ikan berpijah di laut. Larva ikan bandeng wring di jumpai di sepanjang pantai terutama pada bulan — bulan tertentu. Larva terutama di jumpai di sepanjang pantai yang landai, berpasir, dan berair jernih serta kaya akan plankton seperti di daerah pantai utara pulau Jawa, Bali, Lombok, dan pantai Timur Sumatera Utara (Dana, 1990). Musim pemijahan bandeng di Indonesia terjadi dua kali dalam satu tahun yaitu bulan Februari - Mei dengan puncak antara bulan Maret - April dan bulan Juli - Desember dengan puncak antara bulan September - Oktober (Giri et al, 1986).

\section{Siklus Hidup Bandeng (Chanos chanos)}

Siklus hidup bandeng menurut Girl et al, 1986 di mulai dari telur yang menetas menjadi larva (pro - larva dan post - larva), benih bandeng atau juvenil, dan bandeng dewasa.

Menurut Ahmad dan Ratnawati (2002) mulai dari telur bandeng biasanya terbawa arus ke arah pantai yang dihasilkan dan pemijahan dari induk bandeng di perairan pantai. Larva bandeng merupakan bagian dari komunitas plankton di laut lepas yang kemudian hidup dan berkembang. Habitat larva bandeng berada di perairan pantai berpasir, beralrjermh dan banyak mengandung plankton.

Berdasarkan siklus hidupnya benih bandeng yang tertangkap didalam perairan pantai telah mencapai umur tiga - empat minggu, berdasarkan dari pengamatan dari benih yang di hasilkan dari pembenihan dan di bandingkan dengan benih tangkapan di slam di perkirakan benih bandeng yang di tangkap di daerah pantai pada musimnya telah mencapai usia 21 - 25 hari. Larva yang berumur lebih 20 hari di sebut benih. Habitat benih di perairan pantai berkarang atau pasir yang kadang — kadang di tumbuhi vegetasi campuran atau mangrove yang subur, hal ini dikemukan oleh Priyo dan Giri, (1986). Benih bandeng hidup diperairan berlumpur yang sedikit mengandung lumut, sedangkan induk bandeng biasanya berumur lebih dari empat tahun dan panjang total $70-150 \mathrm{~cm}$ hidup diperairan pantai karang didaerah pantai sampai perairan laut dalam (Giri et al, 1986).

Perkembangan Telur Bandeng (Chanos chanos)

Telur ikan ovipar yang belum di buahi mempunyai dua lapis selaput (membran) dari dalam keluar yaitu membran plasma (vitellin) dan membrane kapsul (chorion). Kedua selaput tersebut berlekatan satu sama lain (Blaxter, 1965).

Pada saat terjadi pembuahan (fertilisasi), sperma masuk kedalam telur melalui micropyle yang terdapat pada chorion. Adanya aktivasi oleh sperma menyebabkan perubahan fisikokimia pada telur. Cytoplasma (ovoplasma) mengalami pengkerutan (kontraksi) oleh pecahnya rongga alveoli di dalam telur. Pengkerutan tersebut menyebabkan 
terbentuknya ruang diantara membrane vitelline dan chorion yang disebut ruang perivitelline. Ruang tersebut kemudian terisi cairan alveoli berupa koloid polisakarida yang disebut cairan perivitelline (Blaxter, 1965). Disamping terjadi pula proses imbibisi air pada chorion sehingga chorion mengembang dan menebal yang berakibat ruang perivitelline yang terbentuk bertambah besar. Adanya ruang perivitelline memungkinkan pergerakan embrio selama proses perkembangan sampat menetas.

Penebalan chorion disertai pula dengan pengerasan chorion yang dimungkinkan oleh adanya glycoprotein, koloid, ion $\mathrm{Ca}$, dan aktivitas enzim. chorion yang keras ini merupakan lapisan pelindung embrio terhadap pengaruh dari luar, antara lain : benturan fisik, invasi mikroorganisme, dll (Blaxter, 1965).

Telur bandeng yang telah dibuahi bersifat pelagik pada air laut normal. Telur bersifat trasparan dengan diameter rata-rata sekitar 1,2 mm (1,10 - 1,25 $\mathrm{mm}$ ) dan bervariasi tergantung lokasi geografi, ras, dan individu (Anonim, 1990). Peleburan sperma dan sel telur (Inti dan ovoplasma) mengalami proses pembelahan secara mitosis (segmentasi). Pembelahan zygote menjadi blastomer berlangsung terus menerus sehingga ukuran sel semakin mengecil. Proses pembelahan ini bertujuan mempersiapkan sel-sel untuk membangun tubuh. Selama proses pembelahan volume sel keseluruhan masih sama dengan volume zygote karena belum terjadi pertumbuhan (Sterba, G. 1989).

Menurut Chauduri, H. (1977) telur bandeng menetas dalam waktu $25-28,5$ jam setelah pemtjahan pada suhu $26,4-29,0^{\circ} \mathrm{C}$. Pada bagian cangkang telur bandeng (chorion) yang pecan kepala, embrio keluar terlebih dahulu. Seballknya pada ikan lain umumnya Ujung ekor keluar terlebih dahulu. Persentase penetasan telur bandeng berkisar antara 15,34 - 92,60 $\%$ dengan rerata 48,19\% (Girl et al,. 1986).

\section{Penyakit Ikan}

Menurut Afrianto (1992) penyakit ikan adalah segala sesuatu yang dapat menimbulkan gangguan pada ikan, baik secara langsung maupun tak langsung. Gangguan terhadap ikan dapat disebabkan oleh organisme lain, pakan maupun kondisi lingkungan yang kurang menunjang kehidupan ikan. Dengan demikian timbulnya serangan penyakit ikan di kolam merupakan basil interaksi yang tidak serasi antara ikan, kondisi lingkungan dan organisme penyebab penyakit.
Manusia memegang peranan penting dalam upaya pencegahan timbulnya serangan penyakit pada ikan di kolam budidaya, yaitu dengan cara memelihara keserasian interaksi antara tiga komponen tersebut. Umumnya wabah penyakit yang menyerang ikan di kolam disebabkan oleh kesalahan manusia dalam mengelola lingkungan kolam (Afrianto dan Liviawati, 1992).

Faktor Lingkungan Yang Mempengaruhi Kesehatan Bandeng (Chanos chanos)

Faktor lingkungan adalah faktor-faktor abiotik yang kurang menunjang bagi kehidupan ikan (Daelami 2001). Menurut Ahmad, dan Ratnawati, E (2002) faktor lingkungan yang menyebabkan penyakit pada ikan adalah sebagai berikut :

a. Suhu Air

Suhu air sangat berkaitan erat dengan konsentrasi oksigen terlarut dalam air dan laju konsumsi oksigen hewan air. Suhu air berbading terbalik dengan konsentrasi jenuh oksigen terlarut, tetapi berbanding lures dengan laju konsumsi oksigen hewan air dan laju reaksi kimia dalam air.

Berdasarkan pengamatan di Instalasi Tambak Percobaan Marana (Sulawesi Selatan), ikan bandeng masih hidup normal pada suhu $27-35^{\circ} \mathrm{C}$. Secara teoritis, ikan tropis masih hidup normal pada kisaran suhu $30-35^{\circ} \mathrm{C}$ kalau konsentrasi oksigen terlarut cukup tinggi.

\section{b. Derajat Keasaman $(\mathrm{pH})$}

Keadaan $\mathrm{pH}$ yang dapat mengganggu kehidupan ikan adalah $\mathrm{pH}$ yang terlalu rendah (sangat asam) atau sebaliknya terlalu tinggi (sangat basa). Setiap jems ikan akan memperlihatkan respon yang berbeda perubahan $\mathrm{pH}$ dan dampak yang di pertimbangkan juga berbeda-beda. Air yang banyak

mengandung $\mathrm{CO} 2$ biasanya mempunyai $\mathrm{pH}$ lebih rendah dari 7 dan bersifat masam. Derajat kemasaman $(\mathrm{pH})$ air sebesar 6,5 - 9,0 sangat memadal bag] budidaya bandeng.

\section{c. Kadar Oksigen Terlarut}

Semakin tinggi kandungan oksigen terlarut dalam air (pada batas-batas tertentu) akan semakin balk untuk keperluan budidaya. Kandungan oksigen yang baik untuk rnengoptimalkan produksi adalah dari $5 \mathrm{mg} / \mathrm{l}$. kandungan oksigen tetap sebesar $3 \mathrm{mg} / \mathrm{l}$ atau $4 \mathrm{mg} / \mathrm{l}$ dalam jangka waktu yang lama, maka ikan akan menghentikan makan dan pertumbuhannya. Pengaruh lain dari kondisi oksigen 
yang lemah adalah menurunya kesehatan ikan sehingga lebih mudah terinfeksi oleh penyakit atau parasit.

\section{d. Salinitas}

Bandeng mampu menyesuaikan diri terhadap salinitas, dapat hidup di air tawar $(\mathrm{S}=<0-5$ $\%$ o) maupun air asin $(\mathrm{S}=30-50 \% \mathrm{o})$. Namun karena bandeng di budidayakan untuk tujuan komersial maka rentang salinitas optimal perlu dipertahankan. Pada rentang salinitas optimal (12-20\%o), energi yang digunakan untuk mengatur keseimbangan kepekaan tubuh dan air tambak cukup rendah hingga sebagian besar energi asal pakan dapat digunakan untuk pertumbuhan.

\section{e. Bahan Organik $\left(\mathrm{NH}_{3}\right.$ dan $\left.\mathrm{H} 2 \mathrm{~S}\right)$}

Sumber utama amonia $\left(\mathrm{NH}_{3}\right)$ adalah bahan organik dalam bentuk sisa pakan, kotoran ikan, maupun dalam bentuk plankton dan bahan organik tersuspensi. Pembusukan bahan organik terutama yang banyak mengandung protein menghasilkan amonium $\left(\mathrm{NH}_{4}^{+}\right)$dan amonia. Bila proses pembusukan tidak berlangsung dengan sempurna maka terjadi penumpukan $\mathrm{NH}_{3}$ sampai pada konsentrasi yang membahayakan ikan. Prosentase $\mathrm{NH}_{3}$ dart amonia total dipengaruhi oleh suhu dan $\mathrm{pH}$ air. Makin tinggi suhu dan $\mathrm{pH}$ air maka makin tinggi pula prosentase konsentrasi NH3. Dengan kata lain, peluang ikan keracunan $\mathrm{NH}_{3}$ lebih besar pada suhu dan $\mathrm{pH}$ tinggi. Bahan organik selain dapat menghasilkan amonia juga memproduksi asam belerang (1-12S). Ikan biasanya kehilangan keseimbangan pada konsentrasi 1-12S 0,1-0,2 mg/It dan pada konsentrasi $0,25 \mathrm{mg} / \mathrm{lt}$ kernatian masal biasanya terjadi.

\section{Penyakit Parasiter Dactylogyrus sp.}

Parasit adalah hewan atau tumbuhan yang hidup pada atau didalam tubuh ikan untuk memperoleh makanan dari inangnya demi kelangsungan hidupnya tanpa memberi imbalan apapun (Daelami, 2001).

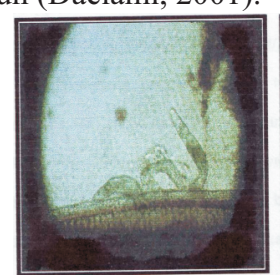

(a)

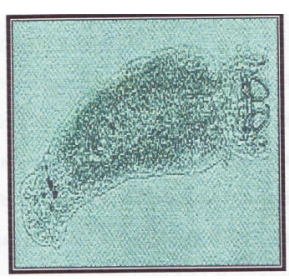

(b)
Gambar 2. Dactylogvrus sp (b) menempel pada bagian insang (a)
Sumber : http://www.geocities.com/Steeward/ dactyl.htm

Secara taksonomi Dactylogyrus sp menurut Amlacher (1961) adalah sebagai berikut :

$\begin{array}{ll}\text { Phylum } & \text { : Plathyhelmintes } \\ \text { Klas } & \text { : Trematoda } \\ \text { Ordo } & \text { : Dactylogyridea } \\ \text { Famili } & \text { : Dactylogyridae } \\ \text { Genus } & \text { : Dactylogyrus } \\ \text { Species } & \text { : Dactylogyrus } s p\end{array}$

Dactylogyrus sp. termasuk golongan treinatoda monogenea, mempunyai siklus hidup langsung dimana cacing muda mirip dengan cacing dewasa, hermaprodit karena memiliki organ reproduksi jantan dan betina, memiliki 14 kait sisi, dua diantaranya jauh dari sisi dan menutup organ penempel. Di belakang terdapat kait lurus ke belakang dengan, satu atau dua saling menyilang (http://www.pestforum.com/cis fishnet/JAAS).

Penularan parasit ini dapat terjadi lewat saluran pencernaan (usus), terbawa oleh aliran darah dan selanjutnya dinding spora akan larut dan keluarlah hewan yang bergerak seperti arnuba yang masuk ke saluran darah dan menyebar ke seluruh tubuh untuk membentuk bintil baru yang siap menyebarkan spora. Penyebaran spora dapat terjadi jika ikan mati atau melalui luka pada tubuh ikan (Afrianto clan Liviawati, 1992). Sedangkan menurut Trimariani dan 1. Rustikawati (1990), penyakit yang ditimbulkan oleh Dactylogyrus sp. disebut Helminthiasis. Dengan gejala antara lain : kulit memucat, hyperplasia epithelium, nampak kromatofor, bintik merah berlendir banyak, sisik terlepas dan badan menjadi kurus (Anonim, 1990).

Ductylogyrus sp. merupakan parasit yang sering menyerang pada insang terutama pada ikan bandeng. Parasit ini selama hidupnya berada pada tubuh ikan dan hanya akan meninggalkan inangnya apabila inangnya mati, kemudian ratusan larva Dactylogyrus sp. yang baru menetas akan mencari inang baru. Gejala yang dapat diamati pada ikan yang terinfeksi parasit Dactylogyrus sp. adalah :

- Frekuensi pernafasan ikan meningkat

- Ikan kehilangan keseimbangan untuk berenang

- Kulit banyak mengeluarkan lendir

- Warna tubuh pucat

- Siri-siripnya menguncup 
Insang yang terserang Dactylogyrus sp. berwarna pucat dan putih dengan kista berwarna gelap yang berbentuk lonjong atau memanjang (Duijn, C.V..I, 1973). Dactylogyrus sp. akan tampak seperti benjolan yang menyerupai tumor atau bintilbintil berwarna putih kemerahan yang menyebabkan tutup insang akan terlihat selalu terbuka (Anonim, 1993). Fungsi pernafasan pada insang kemungkinan akan melemah akibat sebagaian besar permukaan lembaran insang yang digunakan untuk pertukaran gas ditutupi oleh kista. Kondisi insang menjadi parah ketika kista pecah sehingga menyebabkan nekrosis pada jaringan dan ikan mati karena fungsi pernafasannya terganggu (Dana, 1990). Serangan yang berat pada jaringan dibawah kulit dan insang menyebabkan gerakan ikan lambat, warna tubuh menjadi gelap, dan lemahnya system syaraf ( Dana, 1990).

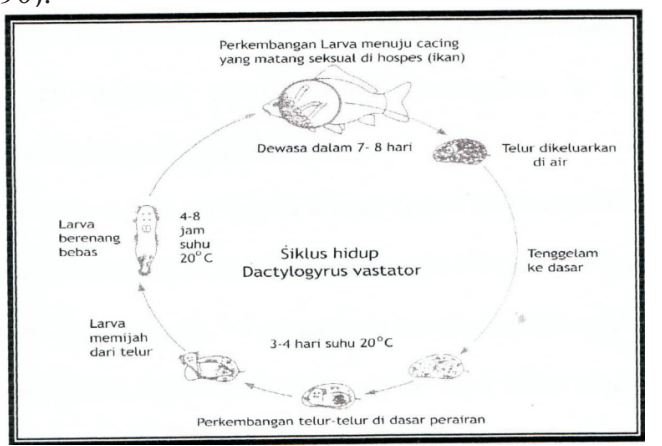

Gambar 3. Siklus Hidup Dactylogyrus sp.

Dactylogyrus sp. dimasukkan kelompok monogenia karena memiliki siklus hidup langsung, tanpa memerlukan inang perantara. Memiliki tahap perkembangan sebagai berikut : telur - larva dewasa (Schaperclaus, 1992).

Telur Dactylogyrus sp. memiliki ukuran 20 $-600 \mu \mathrm{m}$, jarak antara telur ditelurkan dan penetasan berkisar antara $2-150$ hari pada suhu $10^{\circ} \mathrm{C}-30^{\circ} \mathrm{C}$ (Harrison, 1991). Ovipar bentuk bervariasi, sebagian besar ditelurkan pada malam hari, menetas antara 3 47 hari setelah ditelurkan, penetasan dirangsang oleh bahan kimiaw (mucus), lingkungan (cahaya, suhu). Gangguan fisik (kontak) (http://www.pestforum.com/ cis fishnet/JAAS).

Selama pematangan telur turun kedasar dan berkembang, berubah menjadi larva yang kaitnya bersilia dan siap untuk menetas. Periode yang diperlukan untuk perkembangan antara 27 - 28 hari suhu $8^{\circ} \mathrm{C}, 10$ - 15 hari suhu 12 T., 3 - 5 hari suhu 20 $\mathrm{T}$ dan $1-4$ Kati suhu $24-28{ }^{\circ} \mathrm{C}$ (Schaperclaus, 1992). Rata - rata penetasan telur tergantung suhu, pada suhu yang rendah maka memerlukan berbulan- bulan untuk menetaskan, sedang pada suhu tinggi akan menetas sekitar 4 hari hal ini membuat penanggulangan Dactylogyrus sp. sangat sulit (http://www.pestforum.com/cis fishnet/JAAS).

Tahap larva pada monogenea dikenal dengan Oncomiracidium, berenang bebas diinang, bentuk silindris, ukuran panjang 100-300 pm dan lebar 30-100 $\mu \mathrm{rn}$ mempunyai kelenjar cepalik, 1-2 pasang mata dan struktur dindmg ekskreton dan penceniaan terpisah, berenang bebas diinang dan dapat hidup bebas selain 4-5 jam di air kemudian mati (Horrison, 1991). Setelah menetas umumnya bertahan hidup 12-24 jam, mungkin hidup tiga hari lebih sebelum penyerangan ke inang (http://www.pestforum.com/cis fishnet/JAAS). Monogenea dewasa tumbuh langsung dari Oncomiracidnini, bentuknya memanjang, ovoid, panjang cacing dewasa antara 0,1 - $20 \mathrm{~mm}$ tapi secara umum sekitar 1-5 mm (Horrison, 1991). Panjang 0,4-2 mm, lebar 0,1-0,4 (Schaperclaus, 1992).

Menurut Affianto (1992), parasit Dactylogyrus sp. memiliki empat fase dalam siklus hidupnya yaitu :

1. Fase Parasites yaitu saat parasit berada dalam tubuh ikan dan berkembang menjadi dewasa.

2. Fase Pre - Cyste yaitu setelah cukup dewasa dan melepaskan diri dari tubuh inang serta mencari tempat untuk melekat diri. Apabila pada fase ini parasit tidak segera menemukan inang maka parasit akan mati.

3. Fase Cyste yaitu setelah la menemukan tempat menempel dan membentuk kista serta membelah diri dalam kista. Pada fase ini terjadi perbanyakan jumlah individu.

4. Fase Post - Cyste yaitu setelah keluar dari kista dan siap menginfeksi ikan.

Tingkat Serangan Dactylogyrus sp.

Dalam usaha budidaya bandeng secara intensif, blasanya bertumpu pada pakan, padat penebaran, dan pengadaan benih. Agar intensifikasi berhasil dengan baik maka di perlukan ketersediaan benih dalam jumlah yang cukup dan sehat. Menurut Moller dan Anders (1986), dengan adanya pembuahan buatan produksi benih dapat tercapal akan tetapi kematian benih lebih sering terjadi karena penyakit parasiter, diantaranya yang sering menimbulkan kerugian adalah Dactylogyrus sp.

Tingkat kerugian yang disebabkan Dactylogyrus sp. diketahui dari prevalensi, derajat insidensi, dan tingkat kematiannya. Menurut 
penelitian Mulyana et al, (1990), bahwa Dactylogyrus sp. yang menyerang insang ditemukan pada benih mulai terlihat setelah bandeng berumur kira - kira 1,5 - 2 bulan. Berdasarkan penelitian komarudin et al (1991), bahwa rendahnya derajat kelangsungan hidup benih bandeng disebabkan oleh adanya infeksi parasit. Infeksi parasit ini dapat terjadi dalam kondisi padat penebaran yang tinggi, sehingga parasit ikan dapat dengan muda menginfeksi dari satu ikan ke ikan lainnya dengan cara kontak tubuh. Selain itu, penularan melalul kualitas air karena terjadinya akumulasi bahan organik juga mengakibatkan stress pada ikan (Dalimunthe, 1990) sehingga menyebabkan daya tahan tubuh ikan menurun dan mudah terjangkiti penyakit. Dengan demikian infeksi parasit menjadi salah satu faktor pembatas dalam usaha memproduksi ikan karena pengaruh yang ditimbulkan yaitu kematian dapat menyebabkan menurunnya produksi ikan (Dalimunthe, 1990).

\section{Tanda-tanda Infeksi Dactylogyrus sp.}

Dactylogyrus sp. umumnya menyebar cukup cepat. Pada awalnya terdapat beberapa ikan muda yang terpengaruh, tetapi jumlah ikan yang terkena penyakit tersebut meningkat dalam jangka waktu beberapa hari. Ikan muda yang terkena penyakit menjadi gelisah dan berkumpul pada aliran air atau permukaan air, dimana ikan muda tersebut menarik nafas, karena respirasi terganggu. Ikan muda yang lebih parah bergerak miring dan mudah ditangkap. Kematian besar-besaran mungkin bertahan selama 5-10 hari dan berhenti setelahnya (akhir dari epidemi). Ikan muda yang terkena penyakit tidak mempunyai nafsu makan dan terlihat kurus, sebagai akibat dari gejala tersebut, kepala menjadi besar tidak proporsional dibandingkan dengan tubuh (Scholz, 1999).

Perubahan warna menjadi gelap terlihat diantara ikan yang terkena penyakit. Insang sebagian atau sepenuhnya tertutupi dengan lapisan lendir dan tampak pucat, kadang-kadang menyenipai mosaik (anemia). Bagian tepi insang mempunyai perubahan warna abu-abu dan tampak menggumpal, dan operculum tampak seperti terbuka (Scholz, 1999).

Dactylogyrus sp. menggunakan kaitnya, mempenetrasi kedalam jaringan ikat lamella insang menggunakan kaitnya. Penetrasi tersebut menyebabkan warna filamen insang sedikit pucat. Perubahan warna tersebut disebabkan rusaknya set pendukung filament insang, lamella insang menjadi berbentuk Clavate (membesar pada bagian ujung dari pada bagian dasar) dan terisi dengan darah. Set pada tahap disintegrasi yang berbeda terdapat dalam proliferasi jaringan ikat dari tempat yang terkena pengaruh penyakit. Pendarahan terjadi wiring dengan terjadinya kerusakan dan kehancuran lamella insang. Darah menggumpal antara lamella. Kemungkinan bahwa pendarahan dapat terjadi bahkan ketika kerusakan tidak begitu parah, menunjukkan bahwa parasit menghasilkan substansi yang menyebabkan pendarahan (Scholz, 1999).

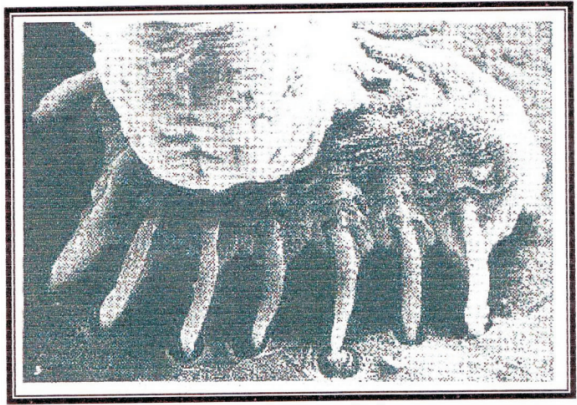

Gambar 4. Kait Dactylogvrus sp. untuk mempenetrasi lamella insang

Sumber : http://edis.ifas.ufl.edu/FA032

Pengertian Prevelansi dan Derajat Infeksi

Untuk memonitor populasi suatu parasit pada ikan dapat dilakukan dengan identifikasi parasit yaitu dengan cara menghitung prevalensi dan derajat infeksinya (Mulyana, 1990).

Prevalensi adalah presentase ikan yang terserang parasit atau proporsi dan organisms organisme dalam keseluruhan populasi yang ditemukan terjadi pada ikan pada waktu tertentu dengan mengabaikan kapan mereka terjangkit. Prevalensi tidak menggambarkan kapan ikan terjangkit parasit atau bagaimana perkembangan parasit. Apabila parasit dapat disembuhkan maka prevalensi tidak menggambarkan jumlah total organisme yang pernah terjangkit pada waktu tertentu, tetapi menunjukkan banyaknya yang kena penyakit (Mulyana et al,. 1990).

Prevalensi dapat dihitung dengan menggunakan rumus :

$$
\text { Prevalensi }=\frac{\text { jumlah } \text { ikan yang terserang penyakit }}{\text { jumlah sample } \text { ikan yang diamati }} \times 100 \%
$$

Sedangkan pengertian dari derajat infeksi adalah jumlah rata — rata parasit per ikan yang terinfeksi dinyatakan dalam parasit/ekor (Mulyana et al, . 1990).

Derajat infeksi dapat dihitung dengan menggunakan rumus :

Derajat infeksi $=\frac{j u m l a h \text { parasit yang menyerang } i \text { kan }}{\text { jumlah } \text { ikan yang terserang parasit }} \times 100 \%$ 


\section{Metodologi}

Waktu dan Tempat Penelitian

Penelitian dilakukan pada bulan Oktober 2007 di Kecamatan Glagah Kabupaten Lamongan. Pemilihan lokasi berdasarkan data Dinas Perikanan kecamatan Glagah Kabupaten Lamongan dimana ketiga desa ini merupakan tambak yang sering terinfeksi penyakit dan mempunyai kualitas air yang jelek. Ketiga desa tersebut antara lain :

a. Desa Dalung, tambak pendederan dengan luas 12 x 9 m terletak diantara lahan-lahan yang digunakan untuk lahan pertanian. Mata air berasal dari Sungai Bengawan Solo yang melewati Lamongan.

b. Desa Rayung, tambak pendederan dengan luas tambak 14 x $11 \mathrm{~m}$. Mata air berasal dari aliran air Bengawan Solo yang mengalir setiap saat.

c. Desa Pedurungan, tambak pendederan dengan luas tambak $17 \times 12 \mathrm{~m}$. Mata air berasal dari buangan-buangan dari petambak lainnya.

d. Identifikasi parasit dilakukan di Laboratorium Program Studi Biologi FMIPA ITS Surabaya.

Alat, bahan dan cara kerja

Pengambilan Sampel Benih Bandeng (Chanos chanos)

Penelitian ini menggunakan metode eksperimen dengan teknik pengambilan sample secara acak. Sampel yang diambil adalah benih banding (C. chanos) berumur 2 bulan dengan ukuran kira - kira 6 - $7 \mathrm{~cm}$ sebanyak 5 ekor per tambak sebanyak tiga kali ulangan. Sehmgga jumlah sampel seluruhnya yang diambil adalah 15 ekor tiap tambak pembenih. Dalam satu tambak jumlah bandeng kurang lebih 100 ekor. Menurut penelitian Prasetya. et al. 2004, pengambilan sampel sebanyak 5\% sudah mewakili dari seluruh populasi di tambak. Parameter yang diamati adalah Dactylogyrus sp. yang ditemukan. Sampel Bemh bandeng (C. chanos) kemudian dibawah ke Laboratorium Program Studi Biologi FMIPA ITS Surabaya untuk diamati bagian insangnya.

Pengamatan Dactylogyrus sp.

Pengamatan Dactylogyrus sp. pada insang benih bandeng (Chanos chanos) dilakukan dengan cara menusuk bagian kepala (otak) menggunakan skalpel, kemudian tutup insang (operculum) dan lembaran insang digunting. Masing-masing lembaran insang baik kiri maupun kanan diletakkan diatas gelas benda, kemudian dikerok dengan skalpel dan ditetesi satu tetes larutan garam fisiologis $(0,85 \%$
$\mathrm{NaCL})$ setelah itu preparat ditutup dengan gelas penutup. Preparat tersebut kemudian diamati dibawah mikroskop dengan perbesaran $400 \mathrm{x}$, dan dihitung banyaknya Dactylogyrus sp. dengan hand counter

Identifikasi Dactylogyrus sp mengacu pada pustaka dari Schaperclaus, W. 1992. Fish Disease Volume 2. Banyaknya Dactylogyrus sp. kemudian dihitung prevalensi dan derajat infeksinya dengan rumus :

a. Analisis Data Prevalensi

Prevalensi $=\frac{\text { jumlah ikan yang terserang penyakit }}{\text { jumlah sample } \text { ikan yang diamati }} \times 100 \%$

\section{b. Analisis Data Derajat Infeksi}

Derajat infeksi $=\frac{j u m l a h \text { parasit yang menyerang } i \text { kan }}{\text { jumlah } \text { ikan yang terserang parasit }} \times 100 \%$

Analisa Kualitas Perairan

Pengamatan kualitas air berfungsi untuk mengetahui karakteristik dari perairan pada saat pengumpulan data di ketiga lokasi. Pengamatan kualitas air dilakukan pada setup pengambilan sampel. Kualitas air yang diukur meliputi :

a. Suhu Air

b. $\mathrm{pH}$ Air

c. Salinitas

d. Oksigen Terlarut

e. Bahan Organik $\left(\mathrm{NH}_{3}\right.$ dan $\left.\mathrm{H} 2 \mathrm{~S}\right)$

Rancangan Penelitian

Rancangan penelitian ini menggunakan Rancangan Acak Lengkap (RAL). Pengambilan sampel benih bandeng di tiap tambak pembenih di ulang sebanyak 3 kali. Parameter yang diamati adalah Dactylogyrus sp yang ditemukan.

Analisa Data

Data yang telah diperoleh berupa Prevalensi dan Derajat infeksi Dactylogyrus sp. dianalisa dengan Anova (Analysis of Varians). Jika terdapat perbedaan prevalensi dan derajat infeksi antar tambak pembenih maka untuk mengetahui tambak mana yang berbeda digunakan uji LSD (Least Significan Difference) dengan taraf a $=5 \%$ (Gomez, 1995)

\section{Hasil dan Pembahasan}

Prevalensi Dactylogyrus sp. Pada Insang Benih Bandeng (Chanos chanos)

Populasi suatu parasit pada ikan dapat dimonitor melalui identifikasi parasit yaitu dengan 
cara menghitung prevalensi dan derajat infeksinya (Mulyana, 1990). Prevalensi adalah presentasi ikan yang terserang penyakit dibagi dengan jumlah sampel ikan yang diamati. Prevalensi hanya untuk mengetahui presentase jumlah ikan yang terserang penyakit disetiap lokasi. Sedangkan untuk mengetahui kelimpahan atau besarnya serangan parasit pada ikan per individu dilakukan dengan cara menghitung derajat infeksi, sehingga dapat diketahui berapa besar tingkat serangan parasit pada tiap ikan.

Hasil uji statistik ANOVA (Analisis Variansi) dan LSD (Least Significant Difference) pada taraf $5 \%$ diketahui bahwa rata-rata prevalensi Dactylogyrus sp. pada insang benih bandeng (C. chanos) di desa Dalung (53,33 \%) dengan Rayung $(66,67 \%)$ tidak berbeda nyata. Desa Rayung $(66,67$ $\%$ ) dengan desa Pedurungan (86,67\%) juga tidak berbeda nyata tapi antara desa Dalung dengan dengan desa Pedurungan berbeda nyata (Tabel 1).

Tabel 1. Prevalensi Ductylogyrus sp. pada insang benih bandeng (C. chanos) di kecamatan Glagah Kabupaten Lamongan

\begin{tabular}{|c|c|c|c|c|}
\hline \multirow[b]{2}{*}{ Desa } & \multicolumn{3}{|c|}{ Prevalensi (\%) } & \multirow{2}{*}{$\begin{array}{c}\text { Rata-rata } \\
(\%)\end{array}$} \\
\hline & $\begin{array}{c}\text { Ulangan } \\
\text { I }\end{array}$ & $\begin{array}{c}\text { Ulangan } \\
\text { II }\end{array}$ & $\begin{array}{c}\text { Ulangan } \\
\text { III }\end{array}$ & \\
\hline Dalung & 40 & 60 & 60 & $53,33^{\mathrm{a}}$ \\
\hline Rayung & 80 & 60 & 60 & $66,67^{\mathrm{ab}}$ \\
\hline Pedurungan & 80 & 80 & 100 & $86,67^{\mathrm{b}}$ \\
\hline
\end{tabular}

Keterangan : Angka-angka yang di ikuti huruf yang sama tidak berbeda nyata pada taraf $5 \%$ berdasarkan uji LSD

Grafik rata-rata prevalensi Dactylogyrus sp. pada insang benih bandeng (C.chanos) di kecamatan Glagah kabupaten Lamongan (Gambar 5) menunjukkan bahwa tingkat serangan Dactylogyrus $s p$ yang paling tinggi terjadi di desa Pedurungan yaitu sebesar $86,67 \%$.

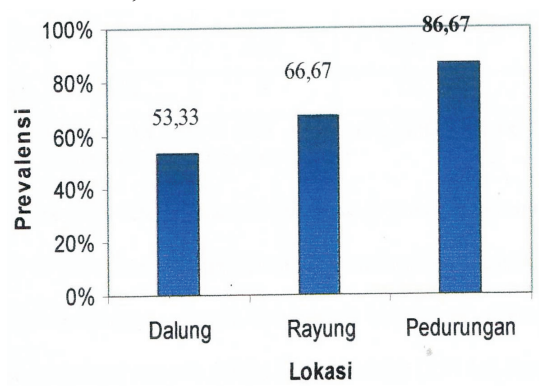

Gambar 5. Grafik rata-rata prevalensi Dactylogyrus sp. pada insang benih Bandeng (C.chanos) di Kecamatan Glagah Kabupaten Lamongan
Derajat Infeksi Dactylogyrus sp. Pada Insang Benih Bandeng (C. chanos)

Derajat infeksi adalah jumlah rata - rata parasit per ikan yang terinfeksi dinyatakan dengan parasit/ekor. Hasil uji statistik ANOVA (Analisis Vuriansi) dan LSD (Least Significant Difference) pada taraf $5 \%$ diketahui bahwa terdapat perbedaan yang nyata disetiap lokasi penelitian, Desa Dalung sebesar 2,06 ind. Parasitlekor, Desa Rayung sebesar 6 ind. Parasit/ekor dan Desa Pedurungan sebesar 7,95 ind. Parasit/ekor. Derajat infeksi Dactylogyrus sp di desa Pedurungan menunjukkan rata-rata yang lebih tinggi di bandingkan dengan derajat infeksi di desa Dalung dan desa Rayung (Tabel 2).

Tabel 2. Derajat infeksi Ductylogyrus sp pada insang benih bandeng (C. chanos) di kecamatan Glagah Kabupaten Lamongan

\begin{tabular}{clccc}
\hline \multirow{2}{*}{ Desa } & \multicolumn{3}{c}{ Derajat Infeksi } & \\
\cline { 2 - 4 } & $\begin{array}{c}\text { Ulangan } \\
\text { I }\end{array}$ & $\begin{array}{c}\text { Ulangan } \\
\text { II }\end{array}$ & $\begin{array}{c}\text { Ulangan } \\
\text { III }\end{array}$ & Rata-rata \\
\hline Dalung & 2,5 & 2,67 & 1 & $2,06^{\mathrm{a}}$ \\
Rayung & 6 & 5,67 & 6,33 & $6^{\mathrm{b}}$ \\
Pedurungan & 8,25 & 8 & 7,6 & $7,95^{\mathrm{c}}$ \\
\hline
\end{tabular}

Keterangan : Angka-angka yang di ikuti huruf yang sama tidak berbeda nyata pada taraf $5 \%$ berdasarkan uji LSD

Grafik rata-rata derajat infeksi Dactylogyrus sp pada insang benih bandeng ( $C$. chanos) di kecamatan Glagah kabupaten Lamongan menunjukkan bahwa derajat infeksi Dactylogyrus sp pada insang benih bandeng (C. chanos) di desa Pedurungan mempunyai reta-rata derajat infeksi tertinggi (7,95 ind. Parasit/ekor), di ikuti desa Rayung (6 ind. Parasit/ekor), dan desa Dalung (2,06 ind. Parasit/ekor).

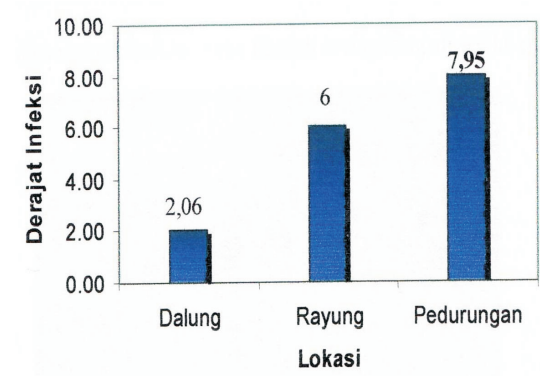

Gambar6. Grafik rata-rata derajat infeksi Dactylogyrus sp pada insang benih bandeng ( $C$. chanos) di kecamatan Glagah Kabupaten Lamongan 
Prevalensi dan Derajat Infeksi Dact'logyrus sp Pada Insang Benih Bandeng (Chanos chanos)

Penyakit ikan adalah segala sesuatu yang dapat menimbulkan gangguan pada ikan baik secara langsung atau tidak langsung. gangguan itu dapat disebabkan oleh organisme lain, pakan atau kondisi lingkungan yang kurang menunjang kehidupan ikan. Timbulnya serangan penyakit ikan di tambak merupakan basil interaksi yang tidak serasi antara ikan, kondisi lingkungan dan organisme penyakit (Afrianto\&Liviawati, 1992).

Hasil pengamatan mikroskopis Dactylogyrus sp yang di temukan di insang benih bandeng (C. chanos) pada semua lokasi penelitian adalah Dactylogyrus sp pada fase dewasa dengan ciri morfologi tubuh berbentuk seperti daun, mempunyai sucker tunggal dengan beberapa kait sebagai organ untuk menempel pada inang (Gambar 7).

Kait tersebut akan masuk ke dalam jaringan ikat pada lamela insang sehingga mengakibatkan wawa filamen insang menjadi sedikit pucat.

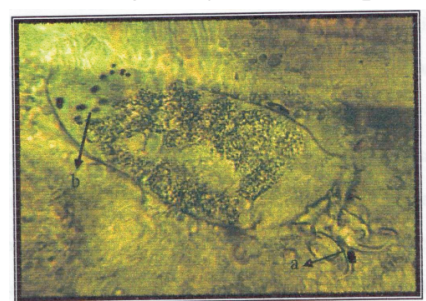

Gambar 6. Daglylogyrus sp hasil penelitian yang ada di insang benih bandeng (Chanos chanos). Keterangan : kart (a), mata (b). Perbesaran $100 \mathrm{X}$

Rata-rata prevalensi $(86,67 \%)$ dan derajat infeksi (7,95 ind. Parasit/ekor) di desa Pedurungan lebih tinggi di bandingkan dengan dua desa lainnya (desa Dalung prevalensi 53,33 derajat infeksi 2,06 ind. parasit'ekor dan desa Rayung prevalensi 66,67 derajat infeksi 6 ind. parasit/ekor). Prevalensi Dactylogyrus sp di desa Pedurungan ini tergolong tinggi, didasarkan atas penelitian Senni (2002) bahwa nilai prevalensi di atas $70 \%$ menunjukkan tingkat serangan parasit yang tinggi sedangkan nilai dibawah $70 \%$ tergolong rendah. Tetapi bila dilihat pada nilai derajat infeksinya sebesar 2,06 - 7,95 parasit per ekor tergolong rendah (Tabel 4.2), didasarkan pada penelitian Desrina (2002) y 9 menyatakan bahwa derajat infeksi 4,5-8,8 parasit/ekor tergolong tidak tinggi. Selain itu berdasar penelitian Uspenskaja (1961) dalam Scharperclaus (1992) menyatakan bahwa derajat infeksi Dactylogyrus sp yang tinggi dan dapat menimbulkan kematian jika nilainya rata- rata 102,6 parasit/ekor (ukuran panjang tubuh ikan rata-rata $21,6 \mathrm{~mm}$ ). Kisaran panjang tubuh bandeng yang digunakan dalam penelitian ini adalah $5-10 \mathrm{~cm}$, sehingga jika diubah dengan nilai yang sama, maka derajat infeksi yang tinggi yang dapat menyebabkan kematian bandeng $90 \%$.

Berdasarkan Tabel 1 prevalensi Dactylogyrus sp desa Pedurungan mempunyai nilai paling tinggi yaitu $86,67 \%$. Tingginya nilai tersebut di duga disebabkan oleh lingkungan perairan yang buruk. Menurut Noble \& Noble (1989) prevalensi parasit juga disebabkan oleh lingkungan perairan yang buruk yang menunjang parasit dapat tumbuh dan berkembang.

Hasil pengukuran kualitas air seperti tingginya salinitas, rendahnya DO, dan tingginya $\mathrm{NH}_{3}$ ( Tabel 4.3 ) di semua lokasi penelitian, terutama desa Pedurungan menunjukkan kualitas air yang buruk. Kisaran DO yang diamati adalah 3,40- 4 ppm, pada kisaran ini ikan dapat hidup tetapi pertumbuhannya terhambat Berta mengalami sires, sehingga menyebabkan turunnya daya tahan tubuh ikan bandeng. Hal ini sesuai dengan basil penelitian Afrianto dan Liviawaty (1992) yang menyatakan bahwa kisaran DO normal yang baik untuk pertumbuhan ikan adalah diatas 5 ppm. Kandungan DO yang rendah (dibawah 5 ppm) akan mempengaruhi suplai oksigen ketubuh ikan berkurang sehingga proses respirasi juga akan terganggu dan akibatnya ikan mengalami stres.

Kualitas perairan yang lain seperti halnya pH di tiap-tiap desa tersebut apabila dibandingkan dengan $\mathrm{pH}$ perairan yang ideal bagi kehidupan ikan ternyata masih memiliki kriteria yang layak. Hal ini dikemukakan oleh Boyd dan Lichtkoppler (1979), bahwa nilai $\mathrm{pH}$ yang berkisar antara 6,9-8,0 masih memenuhi kriteria rata-rata yang layak untuk produksi benih. Walaupun kisaran $\mathrm{pH}$ di tiap-tiap desa tersebut layak untuk kehidupan benih namun justru meningkatkan prevalensi Dactylogyrus sp. Hal ini diduga bahwa kondisi $\mathrm{pH}$ perairan yang ideal bagi kehidupan benih tersebut cocok bagi perkembangan siklus hidup dan penyebaran Dactylogyrus sp (Schaperclaus, 1992).

Kisaran suhu di desa Dalung sebesar $27^{\circ} \mathrm{C}$, desa Rayung berkisar antara $27-28^{\circ} \mathrm{C}$, clan desa Pedurungan sebesar $28{ }^{\circ} \mathrm{C}$ dinilai tidak begitu membahayakan bagi ikan. Karena menurut Ahmad, T dan Ratnawati, E (2002) ikan bandeng masih hidup normal pada suhu $27-35{ }^{\circ} \mathrm{C}$. Tetapi kondisi suhu yang semakin tinggi justru memberi peluang bagi berkembangnya parasit Dactylogyrus sp. Hal ini 
Tabel 3. Hasil pengukuran kualitas air dari tambak pengambilan sampel bench Bandeng (C. chanos) di Kabupaten Lamongan

\begin{tabular}{|c|c|c|c|c|c|c|c|c|c|c|c|c|}
\hline \multirow[t]{2}{*}{ Desa } & \multicolumn{3}{|c|}{$\begin{array}{l}\text { Suhu Air } \\
\text { (Celcius) }\end{array}$} & \multicolumn{3}{|c|}{$\begin{array}{c}\text { DO } \\
\text { (mgi) }\end{array}$} & \multicolumn{3}{|c|}{$\begin{array}{c}\text { Salinitas } \\
(\% / 00)\end{array}$} & \multicolumn{3}{|c|}{$\mathrm{pH}$} \\
\hline & I & II & III & I & II & III & I & II & III & I & II & III \\
\hline Dalung & 27 & 27 & 27 & 4,00 & 4,00 & 4,01 & 10 & 10 & 10 & 7 & 7 & 7 \\
\hline Rayung & 28 & 27 & 27 & 4,00 & 4,00 & 4,00 & 21 & 20 & 21 & 8 & 7 & 8 \\
\hline Pedurungan & 28 & 28 & 28 & 3,40 & 3,39 & 3,40 & 24 & 22 & 23 & 8 & 8 & 8 \\
\hline
\end{tabular}

Keterangan :

I = Pengukuran hari pertama

II $=$ Pengukuran hari kedua

III = Pengukuran hari ketiga

didukung oleh pernyataan Schaperclaus (1992) dimana parasit Dactylogyrus sp selain sering menyerang pada musim kemarau, juga memerlukan waktu untuk berkembangbiak antara 27 - 28 hari suhu $8^{\circ} \mathrm{C}, 10$ - 15 hari suhu $12{ }^{\circ} \mathrm{C}, 3$ - 5 hari suhu 20 ${ }^{\circ} \mathrm{C}$ dan $1-4$ hari suhu $24-28{ }^{\circ} \mathrm{C}$ (Schaperclaus, 1992). Rata - rata penetasan telur tergantung suhu, pada suhu yang rendah maka memerlukan berbulanbulan untuk menetaskan, sedang pada suhu tinggi akan menetas sekitar 4 hari hal ini membuat penanggulangan Dactylogyrus sp sangat sulit (http//www.fishnet/disease.htm).

Kondisi kualitas perairan yang tidak begitu baik disemua lokasi mengakibatkan benih bandeng menjadi stres dan menurun daya tahan tubuhnyasehingga mudah terserang parasit. Hal ini sesuai dengan hasil penelitian Afrianto dan Liviawaty (1992) yang menyatakan bahwa pengaruh serangan parasit terhadap ikan tergantung dari jenis dan jumlah mikroorganisme yang menyerangnya, tetapi juga dipengaruhi oleh kondisi perairan saat itu dan daya tahan tubuh ikan.

Selain faktor perairan, tingginya prevalensi dan derajat infeksi Dactylogyrus sp di desa. Pedurungan di duga disebabkan oleh kondisi geografi lingkungan tambak pembenih. Hal ini dilihat dari keberadaan lokasi tambak desa Pedurungan paling rendah di banding dengan desa lainnya, sehingga selalu mendapat aliran air dari tambak lainnya. Kondisi demikian memungkinkan larva ektoparasit dari tambak lain masuk kedalam tambak pedurungan (Bhagawati et al, 1991). Larva yang masuk kedalam tambak siap untuk menginfeksi inang baru. Perkembangan larva ini kemudian mencapai dewasa dan matang seksual di insang ikan. Ukuran benih juga mempengaruhi tingginya nilai prevalensi dan derajat infeksi. Fenomena ini menunjukkan bahwa semakin kecil ukuran ikan justru akan semakin rentan terhadap Dactylogyrus sp. Hal ini disebabkan karena pada ukuran benih semua organ tubuh belum berfungsi secara sempurna sehingga dapat dikatakan bahwa benih merupakan fase yang sangat kritis dan mudah terserang parasit (Komarudin, 1991).

\section{Kesimpulan}

Hasil penelitian menunjukkan bahwa tingkat prevalensi Dactylogyrus sp pada insang benih bandeng (chanos chanos) berturut-turut dari yang tertinggi adalah desa Pedurungan $(86,67 \%)$, desa Rayung (66,67 \%) dan desa Dalung (53,33\%). Derajat infeksi Dactylogyrus sp pada insang benih banding (C. chanos) antara desa yang satu dengan yang lainnya menunjukkan perbedaan yang nyata, derajat infeksi Dactylogyrus sp di desa Pedurungan mempunyai rata-rata tertinggi (7,95 ind. Parasit/ekor), diikuti desa Rayung (6 ind. Parasit/ekor), dan desa Dalung (2,06 ind. Parasit/ekor).

Perlu ditakukan penelitian lebih lanjut tentang pengaturan sirkulasi air terhadap tambak pembenih.

\section{Daftar Pustaka}

Anonim, 1993. Petunjuk Pelaksanaan Penanggulangan Penyakit Ikan. Direktorat Bina Sumber Hayati, Direktoraty Jendral Perikanan. Jakarta. 41 p.

Anonim, 1988. Studies on The Maturation and Spawning of Milk Fish in Captivity. Progress Report Oktober - December. USA. $87 \mathrm{p}$

Anonim, 1990. Workshop on Larval Culture of The Milk Fish (Chanoschanos). Gondol Research Station. Bali. Indonesia. Prepared by : The Oceanic Insatute. Hawai. 102 p. 
Ahmad, T, dan Ratnawati, E. 2002. Budidaya Bandeng Secara Intensq' Penebar Swadaya. Bogor.

Afrianto, E dan Liviawaty, E. 1992. Pengendalian Hama \& Penyakit Ikan, Kanisius. Yogyakarta. $89 \mathrm{p}$.

Amlacher, E. 1961. Texbook of Fish Disease (Translated by : D. A. Controy and R. L. Herman).TFH Publication Germany. 302 p.

Balmer, J. H. S, 1965. Development : Eggs ang Larvae., dalam : W. S. Hoar and D. J. Randall (End), Fish Physiologi III. Academic Press. New York.

Bhagawati, D.,Petrus, H. T.,Siti, R., 1991. Mengenal Ektoparasit Penyebab Penyakit Ikan Pada Kolam Rakyat di Desa Beji Purwokerto. KKI Tidak di Publikasikan. Fakultas Biologi UNSOED. Purwokerto.

Brotowidjoyo, M. D.,1987. Parasit dan Parasitisme. Media Sarana Press. Jakarta.

Cahyono, B. 2000. Budidaya Ikan Air Tawar: Ikan Bandeng, Ikan Nila, Ikan Gurami. Cetakan Kelima. Kanisius. Yogyakarta. 113 p.

Cameron, A. 2002. Survey 7bolbox for Aquatic Animal Diseases. A. Practical Manual and Software Package. ACIAR Monograph No.94

Chauduri, H. 1977. Observation on Artivical Fertilization of Eggs and The Embryonic and Larva Development of Milk Fish Chanos chanos. Forsskal. 13 : 95-113.

Chandler, A. C. 1950. Introduction to Parasitology With Special Reference to The Parasites (?I'Afan. John Wiley \& Sons. Inc. New York.36

Dana, D dan S. L. Angka, 1990. 11usalah Penyakit Parasit dan Bakteri Pada Ikan Air Tawar Berta Cara Penanggulangannya. Bala] Penelitian Perikanan Air Tawar, Pusat Penelitian dan Pengembangan Perikanan. Bogor. 10-23 p.

Dana, A. 1990. Analysis of The Effect of rearing Temperature on The Prevalence of Myxosporea in Exsperimentally Infected Common Carp (Cyprinus carpio L.) Asian Fisheries Science. 3:329-335.

Dalimunthe, S. 1990. Jervis ParaW Yang Dyumpai Pada Ikan Yang Di Pelihara Di Jawa Timur. Dalam Prosiding Seminar II Penyakit Ikan dan Uclang. Bala] Penelitian Perikanan Air Tawar, Pusat Penelitian Dan Pengembangan Perikanan, Bogor. 109-115 p.
Djani, S. 1993. Alasalah Penyakit Pada Budidaya Man Laut. Dalam Prosiding Simposium Perikanan I. Jakarta. 157-162 p.

Daelami, D. A. 2001. Agar Man Sehat. Penebar Swadaya, Jakarta. Duijn, C. V. J. 1973. Disease of Fishes. Iliffe Books. London. $372 \mathrm{p}$,

Effendie, M. 1. 1997. Biologi Perikanan. Pustaka Nusatama. Yogykarta. 163 p.

Effendie, M. I. 1978. Metode Biologi Perikanan I (Saudi Natural History). Fakultas Perikanan IPB. Bogor.

Gomez, K. A and A. A. Gomez. 1995. Prosedur Statistik Untuk Penelitian Pertanian. -bdisi Kedua. Diterjemahkan Oleh E. Sjamsuddin dan Justika. S. Baharsjah. Ul Press. Jakarta. $698 \mathrm{p}$.

Girl, N. A, A. Pn'yono, dan Tridjoko, 1986. Pemijahan dan Pemeliharaan Larva Bandeng (Chanos chanos). Budidaya Pantai H (1-2). Bandung.

Had], S. 1978. Statistika jilid H. Gadjah Mada University Press. Yogyakarta.366 p.

Horrison, F. W, 1991. Microscopic Anatomfnv

Hine, P. M.,B. K. Diggles, M. J. D. Parsons, A. Pringle dan B. Bull. 2002. The Effects of Stresors on The Diamics of Bonamia Exitiosus Hine, Cochennes-Laureau \& Berthe, Infections in Flat Oysters Ostrea Chilensis (Philippi). Jurn of Fish Diseases. $25: 545-554$.

Kabata. 1985. Parasites and Disease Fish Culture in the Tropics. Taylor \& Prancis Inc. Philadelphia. 318 p.

Komarudin, O. 1986. Ketahanan Lima Strain Ikon Mas Terhadap Infeksi, Vvxosporidia. Bulletin Penelitian Perikanan darat. 5(1):13.37

Komarudin, O., O. Praseno, dan Azwar, Z. I. 1991. Infeksi Parasit Pada Benih Ikan Mas Yang Dipelihara di Kolam Dengan Sistem Aerasi. Bulletin Penelitian Perikanan Darat. 10 (1) : 121-125.

Mulyana, R. I. Riadi, S. L. Angka, dan A. Rukyani 1990. Pemakaian Sistem Saringan Untuk Mencegah Infeksi Parasit Pada Benih Ikan. Dalam Prosiding Seminar II Pen - vak-it Ikan Dan Udang. Balai Penelitian Perikanan Air Tawas, Pusat Penelitian Dan Pengembangan Perikanan, Badan Penelitian Dan Pengembangan Pertanian Bagor. 169$173 \mathrm{p}$. 
Moller, H \& K, Anders. 1986. Disease and Parasites oj'A4arjne Fishes. Verlag Moller, Jerman.

Moyle. P. B. and Joseph. J. Cech-Jr. 2000. Fishes An Introduction to Ichthyology. 4 Edition. Prentice-Hall Inc. USA.

Nelson, J.S. 1984. Fishes of The World. 2 Edition. Jonh Wiley Son Inc. USA. 121p.

Nickell, T. A. dan M. S. Ewing. 1989. Dispersal of Ichthyophthirius Hilluflhis (Ciliophora). Proc. Okla. Acad. Sci. 69:23-35.

Noble, E. R. \& Noble, G. A. 1989. Parasitologi Biologi Parasit Hewan. Edisi Kelima. UGM. Press. Yogyakarta.

Post, G. 1983. Textbook of Fish Health. TFH Publication. United States.256 p.

Santoso. B. 1993. Petunjuk Praktis Budidaya Ikan Bandeng. Cetakan Pertama. Kanisius. Yogyakarta. 83 p..

Saanin, H. 1968. Taksonomi dun Kunji Identifikasi Ikan. Binatjipta. Bandung.

Seni, 2001. Derajat Insideni dan Derajat Infeksi Myxobolus sp Pada Insang Benih Karper(Cyprinus carpio) di Kabupaten Yeman. Universitas Gajah Mada.

Scholz, T. 1999. Parasites in Cultured and Feral Fish. Veterinary Parasitology 84 317-335.

Schaperclaus, W. 1992. Fish Disease Volume 2. Rotterdam.
Sterba, G. 1989. Freshwater Fishes of The World. Volume I. Cosmo Publication. New Delhi. 469 p.38Sudarto dan L. Dhanna. 1990. Uji Banding Kelangsungan Hidup Benih Ikan Bandeng (Chanos chanos) Ras local. Bulletin Penelitian Perikanan Darat. 9(1) :104-107.

Sugiyono, 1997. Statistika Untuk Penelitian. Cetakan Pertama. Alfabeta. Bandung. 194 p.

Stickney, R. R. 1994. Principles ofAquacullure. John Wiley and Sons.502 p.

Trimariam, A dan 1. Rustikawati, 1990. Masalah Penyakit Zooparasit Dalam Pemeliharaan Benih Ikan Air Tawar. Dalam Prosiding Seminar H Penyakit Ikan dan Udang. Balai Penelitian Perikanan Air Tawar, Pusat Penelitian Dan Pengembangan Perikanan, Badan Penelitian Dan Pengembangan Pertaman. Bogor. 39-46p.

Ventura, M.T. dan J.M.Grizzle, 1987. Evaluation of portals of entry of Aeromonas hydrophila in Channel catfish. Aquaculture, 65 : 205-214.

Zonneveld, N.,A. Huisman, dan J. H. Boon,1991. Prinsip - Prinsip Budidaya Ikan. Gramedia Pustaka Utama. Jakarta. 336 p. 
